\title{
Pengaruh Perilaku Konsumen terhadap Keputusan Pemilihan Penggunaan KWH Meter Listrik Pascabayar dan Prabayar pada PT PLN (Persero) Ranting Pancur Batu
}

\author{
Toman Sony Tambunan ${ }^{1)}$ \\ ${ }^{1)}$ Sekolah Tinggi Ilmu Ekonomi LMII, Medan, Indonesia \\ Email:toman.tbn@gmail.com ${ }^{l)}$
}

\begin{abstract}
Abstrak
Penelitian ini bertujuan untuk mengetahui pengaruh perilaku konsumen terhadap keputusan pemilihan penggunaan KWh meter Listrik Pascabayar dan Prabayar Pada PT PLN (Persero) Ranting Pancur Batu, Kota Medan. Total populasi adalah 1.595 konsumen. Teknik sampling menggunakan rumus Slovin, dimana sampel diperoleh sebanyak 94 konsumen. Sumber data dalam penelitian ini adalah data primer dan data sekunder, dimana data primer diperoleh dari observasi, wawancara dan kuesioner, sedangkan data sekunder diperoleh dari studi dokumentasi. Analisa data dilakukan dengan analisis deskriptif serta analisis regresi linier sederhana dengan pengujian hipotesis secara uji-t dan koefisien determinasi. Hasil analisis regresi sederhana, yaitu $\mathrm{Y}=18,684+(\mathrm{X})$ $0,668+$ e yang menunjukkan perilaku konsumen mempengaruhi hubungan positif terhadap keputusan pemilihan penggunaan KWh meter Listrik Pascabayar dan Prabayar pada PT PLN Rayon Selatan Medan. Sedangkan hasil uji-t atau uji parsial menunjukkan bahwa perilaku konsumen berpengaruh positif dan signifikan terhadap keputusan pemilihan Penggunaan KWh meter Listrik Pascabayar dan Prabayar. Hal ini dilihat dari nilai thitung $9,187>t_{\text {tabel }} 1,9860$. Hasil nilai regresi korelasi sebesar 0,692, artinya secara bersama-sama perilaku konsumen memiliki kontribusi pada taraf yang erat dan positif terhadap keputusan pemilihan penggunaan KWh meter Listrik Pascabayar dan Prabayar PT PLN (Persero) Ranting Pancur Batu, Kota Medan. Koefisien determinasi $\left(\mathrm{R}^{2}\right)$ sebesar 0.437 (43,7\%), sehingga dapat dikatakan bahwa 43,7\% variasi variabel bebas perilaku konsumen dapat menjelaskan variabel keputusan pemilihan sedangkan sisanya sebesar 57,3\% dijelaskan oleh variabel lain di luar model.
\end{abstract}

Kata Kunci: Perilaku Konsumen, Keputusan Pemilihan, Pembelian, Pemasaran

\begin{abstract}
This study aims to determine the effect of consumer behavior on the decision to choose the use of Postpaid and Prepaid Electricity KWh meters at PT PLN (Persero) Branch of Pancur Batu, Medan City. The population total was 1,595 consumers. The sampling technique uses the Slovin formula, where the sample is obtained as many as 94 consumers. Sources of data in this study are primary data and secondary data, where primary data is obtained from observations, interviews and questionnaires, while secondary data is obtained from documentation studies. Data analysis was carried out by descriptive analysis and simple linear regression analysis with hypothesis testing using t-test and coefficient of determination. The results of simple regression analysis, namely $\mathrm{Y}=18,684+(\mathrm{X})$ $0.668+\mathrm{e}$ indicate that consumer behavior affects a positive relationship with the decision to choose the use of Postpaid and Prepaid Electricity KWh meters at PT PLN Rayon Selatan Medan. While the results of the t-test or partial test show that consumer behavior has a positive and significant effect on the decision to choose the use of Postpaid and Prepaid Electricity KWh meters. This can be seen from the value of tcount 9.187>t table 1.9860. The result of the correlation regression value is 0.692 , which means that together consumer behavior has a close and positive contribution to the decision to choose the KWh meter for Postpaid and Prepaid Electricity PT PLN (Persero) Ranting Pancur Batu, Medan City. The coefficient of determination (R2) is 0.437 (43.7\%), so it can be said that $43.7 \%$ of the variation in the independent variable of consumer behavior can explain the variable of the selection decision, while the remaining $57.3 \%$ is explained by other variables outside the model.
\end{abstract}

Keywords: Consumer Behavior, Selection Decision, Purchasing, Marketing 


\section{Pendahuluan}

Perkembangan teknologi dan arus informasi yang sangat cepat telah mendorong setiap perusahaan untuk menghasilkan produk yang terus menerus baru untuk memenuhi kebutuhan dan keinginan konsumen sehingga konsumen merasa puas dengan apa yang mereka dapat dari produk perusahaan tersebut.

Salah satu perkembangan teknologi yang pesat adalah listrik. Listrik merupakan sumber kehidupan bagi masyarakat yang mempunyai fungsi penting sebagai penerangan dan energi dalam segala aktivitas sehari-hari di era modern yang sepenuhnya membutuhkan sumber daya listrik. Ketergantungan manusia akan kebutuhan listrik sangat dirasakan penting di berbagai sektor untuk menggerakkan berbagai peralatan rumah tangga, industri, perbankan, perusahaan, rumah sakit, hingga pada kebutuhan akan bidang pendidikan. KWh (kilowatt-hour) meter adalah suatu alat ukur yang digunakan untuk menghitung pemakaian energi listrik.

Keberadaan PT Perusahaan Listrik Negara (Persero) atau disingkat dengan PLN sangat penting dalam memenuhi amanat konstitusi yang menyebutkan bahwa segala hal yang berhubungan dengan kekayaan alam dan menyangkut kepentingan orang banyak dikuasai oleh negara. PT Perusahaan Listrik Negara (Persero) sebagai perusahaan listrik di Indonesia memiliki peran dan tanggung jawab dalam memenuhi kebutuhan pasokan listrik kepada masyarakat. Sebelum tahun 2010, PT PLN (Persero) masih menerapkan metode pembayaran listrik pascabayar kepada pelanggannya. Dengan berkembangnya kemajuan teknologi, maka pembayaran listrik sudah menerapkan metode prabayar atau listik pintar, yang dimana memiliki banyak manfaat dan kemudahan kepada masyarakat dalam memenuhi kebutuhan pokok terhadap energi listrik. Pada Tabel 1.1 disajikan jumlah pelanggan listrik Pascabayar dan Prabayar untuk sektor Ranting Pancur Batu di Kota Medan.

Semakin tingginya kebutuhan masyarakat akan penggunaan sumber daya energi listrik, dan didukung dengan adanya kemajuan teknologi, maka akan memberikan dampak perubahan perilaku konsumen dalam menggunakan listrik. Menurut Kotler dan Keller (2008) perilaku konsumen adalah studi bagaimana individu, kelompok dan organisasi memilih, membeli, menggunakan dan menempatkan barang, jasa, ide atau pengalaman untuk memuaskan keinginan dan kebutuhan konsumen.

Kemudahan dan manfaat yang bisa dirasakan bila menggunakan metode listrik Prabayar, menyebabkan pelanggan untuk membuat keputusan pembelian dengan mengganti KWh meter listrik Prabayar. Sehingga hal ini memberikan dampak semakin banyaknya masyarakat yang sebelumnya menggunakan listrik Pascabayar beralih menjadi penggunaan listrik Prabayar. Di samping itu, kebijakan dari PT PLN (Persero) yang mewajibkan bagi pemasangan listrik baru untuk menggunakan metode pembayaran listrik Prabayar, menyebabkan semakin tingginya penggunaan metode pembayaran listrik Prabayar. Menurut Kotler \& Amstrong (2014), keputusan pembelian adalah tahap dalam proses pengambilan keputusan pembeli dimana konsumen benar-benar membeli suatu produk.

Tabel 1 di bawah menunjukkan bahwa jumlah pelanggan listrik pascabayar pada 2016 mengalami penurunan sebanyak 191 pelanggan atau sebesar $1.91 \%$ dari tahun 2015 . Pada tahun 2017 mengalami penurunan sebanyak 679 pelanggan atau sekitar $6.79 \%$ dari tahun 2016 . Tahun 2018 mengalami penurunan sebanyak 199 pelanggan sekitar $1.99 \%$ dari tahun 2017 . Tahun 2019 mengalami penurunan sebanyak 1.117 pelanggan atau sekitar $11.17 \%$ dari tahun 2018 . Sedangkan untuk pelanggan listrik yang Prabayar pada tahun 2016 terus mengalami peningkatan pengguna yaitu sebanyak 1.918 pelanggan atau sekitar $19.18 \%$ dari tahun 2015 . 
Tahun 2017 meningkat menjadi 2.111 pelanggan atau sekitar $21.11 \%$ dari tahun 2016 . Tahun 2018 semakin meningkat menjadi 323 pelanggan atau 3.23\% dari tahun 2017. Tahun 2019 mengalami peningkatan yang signifikan sebanyak 1.968 pelanggan atau sekitar $19.68 \%$ dari tahun 2018.

Tabel 1. Jumlah Pelanggan Listrik Pascabayar dan Prabayar Tahun 2015-2019 pada PT PLN (Persero) Ranting Pancur Batu, Kota Medan

\begin{tabular}{|l|l|l|}
\hline Tahun & Listrik Pascabayar (Pelanggan) & Listrik Prabayar (Pelanggan) \\
\hline 2015 & 15.172 & 4.784 \\
\hline 2016 & 14.981 & 6.702 \\
\hline 2017 & 14.302 & 8.813 \\
\hline 2018 & 14.103 & 9.136 \\
\hline 2019 & 12.986 & 11.104 \\
\hline
\end{tabular}

Berdasarkan informasi diatas, maka rumusan masalah dalam penelitian ini adalah apakah terdapat pengaruh perilaku konsumen terhadap keputusan pemilihan penggunaan KWh meter Pascabayar dan Prabayar pada PT PLN (Persero) Ranting Pancur Batu, Kota Medan.

\section{Tinjauan Pustaka}

\subsection{Perilaku Konsumen}

Berdasarkan Pasal 1 ayat 2 dalam Undang-Undang Republik Indonesia Nomor 8 Tahun 1999 tentang Perlindungan Konsumen, pengertian konsumen adalah setiap orang pemakai barang dan/ atau jasa yang tersedia di masyarakat, baik bagi kebutuhan diri sendiri, keluarga, orang lain, atau mahluk hidup lain dan tidak untuk diperdagangkan.

Menurut Kotler dan Keller (2008) perilaku konsumen adalah studi bagaimana individu, kelompok dan organisasi memilih, membeli, menggunakan dan menempatkan barang, jasa, ide atau pengalaman untuk memuaskan keinginan dan kebutuhan konsumen.

Peter dan Olson (2008) menyebutkan alasan pentingnya mempelajari perilaku konsumen, yaitu:

1. Teori perilaku konsumen menyediakan pertanyaan-pertanyaan krusial yang harus dijawab manager dalam pemasaran produk.

2. Praktik pemasaran dirancang untuk merespon bagaimana perilaku konsumen mempengaruhi perusahaan, individu dan masyarakat.

3. Semua keputusan dan peraturan pemasaran didasarkan pada asumsi-asumsi perilaku konsumen.

4. Keberhasilan dan kegagalan strategi atau program-program pemasaran yang dirancang dan dilaksanakan perusahaan tergantung pada pemahaman tentang perilaku konsumen.

5. Perilaku konsumen menjadi dasar bagi manager pemasaran dan menentukan segmentasi pasar, pemosisian produk, differensi produk, analisis lingkungan, dan kebijkan-kebijakan publik. 
6. Mempelajari perilaku konsumen bermanfaat bagi konsumen agar mereka bisa menjadi konsumen yang cerdas.

7. Teori perilaku konsumen bisa digunakan untuk memahami perilaku manusia secara umum.

8. Dengan mempelajari perilaku konsumen kita bisa mendapatkan beberapa informasi mengenai orientasi konsumen, dan teori yang membimbing proses berfikir konsumen.

Lebih lanjut, Engel, et al. (2006) mengemukakan bahwa perilaku konsumen perlu dipahami oleh produsen atau pemasar, agar bisa memperoleh keuntungan sebagai berikut:

1) Konsumen dengan perilakunya (terutama perilaku beli) adalah wujud dari kekuatan tawar yang merupakan salah satu kekuatan kompetitif yang menentukan intensitas persaingan dan profitabilitas perusahaan.

2) Analisis konsumen menjadi landasan bagi manajemen pemasaran dan akan membantu manager melakukan hal-hal sebagai berikut:
a. Merancang bauran pemasaran
b. Melakukan segmentasi pasar
c. Melakukan pemosisian
d. Melakukan analisis lingkungan perusahaan
e. Pengembangan trend penelitian pasar
f. Mengembangkan produk baru dan inovasi produk

3) Analisis konsumen memainkan peranan yang sangat penting dalam pengembangan kebijakan publik perusahaan.

4) Pengetahuan mengenai perilaku dapat meningkatkan kemampuan pribadi seseorang untuk menjadi konsumen yang lebih efektif.

\subsection{Indikator Perilaku Konsumen}

Kotler dan Keller (2008), menjelaksan ada 3 indikator yang mempengaruhi perilaku konsumen dalam mengambil keputusan, yaitu:

1. Psikologi

Psikologi mencakup persepsi, motivasi, pembelajaran sikap dan kepribadian. Sikap dan kepercayaan merupakan faktor psikologis yang mempengaruhi keputusan pembelian konsumen. Sikap adalah suatu kecenderunganyang dipelajari untuk bereaksi terhadap penawaran produk dalam situasi dan kondisi terstentu secara konsisten.Sikap mempengaruhi kepercayaan dan kepercayaan mempengaruhi sikap. Kepribadian merupakan faktor psikologis yang memengaruhi perilaku konsumen. Kepribadian adalah pola individu untuk merespons stimulus yang muncul dari lingkungannya, termasuk didalam kepribadian adalah opini, minat, dan prakarsa.

Pembelajaran berdampak pada adanya perubahan. Seorang individu/ konsumen dikatakan belajar jika ada perubahan kearah yang lebih baik dalam tiga aspek kognitif, afektif, dan psikomotorik, yang bersifat relatif permanen. Konsumen akan belajar setelah mendapat pengalaman, baik pengalaman sendiri maupun orang lain. Setelah membeli dan mengomsumsi/ memakai produk konsumen akan merasa puas atau tidak puas. Jika puas, 
konsumen akan melakukan pembelian ulang dilain waktu dan sebaliknya jika tidak puas, konsumen tidak akan melakukan pembelian di lain waktu.

2. Situasional

Situasional mencakup keadaan sarana dan prasarana tempat belanja, waktu berbelanja, penggunaan produk, dan kondisi saat pembelian. Keadaan sarana dan prasarana tempat belanja mencakup tempat parkir, gedung, eksterior, interior dan pendingin udara, penerangan/ pencahayaan, tempat ibadah dan sebagainya. Waktu berbelanja bisa pagi siang sore atau malam hari. Waktu yang tepat untuk berbelanja bagi setiap orang tentu berbeda. Orang yang sibuk bekerja pada malam hari akan memilih waktu belanja pada sore atau malam hari. Kondisi saat pembelian produk adalah sehat, senang, sedih, kecewa, atau sakit hati. Kondisi saat pembelian produk adalah saat melakukan pembelian akan memmengaruhi pembuatan keputusan konsumen.

3. Sosial dan Budaya

Sosial budaya mencakup undang-undang /peraturan, keluarga, kelompok referensi, kelas sosial, dan budaya.

a) Sebelum memutuskan untuk membeli produk, konsumen akan mempertimbangkan apakah pembelian produk tersebut diperbolehkan atau tidak oleh undang-undang yang berlaku. Jika diperbolehkan konsumen akan melakukan pembelian. Namun jika dilarang oleh undang-undang atau peraturan (daerah, regional, nasioanl, bahkan internasional) konsumen tidak akan melakukan pembelian.

b) Keluarga terdiri dari ayah ibu, ibu dan anak. Anak yang baik tentu akan melakukan pembelian produk jika ayah dan ibunya menyetujuinya.

c) Untuk kelompok referensicontohnya kelompok referensi untuk ibu-ibu (kelompok pengajian, PKK, dan arisan) tim bola (kelompok boy band, girl band, tim basket idola dan tim bola terkenal) dan bapak-bapak (kelompok pengajian, penggemar motor besar, kelompok penggila bola, dan sebagainya)

d) Untuk kelas sosial yang ada dimasyarakat, contohnya kelas atas, menengah dan bawah.

e) Untuk budaya dan sub-budaya contohnya suku sunda, jawa, batak, Madura. Tiap suku/etnis mempunyai budaya atau sub-budaya yang berbeda.

\subsection{Keputusan Pembelian}

Keputusan pembelian merupakan suatu bagian terpenting dalam mempengaruhi perilaku konsumen terhadap suatu pembelian produk atau jasa (Marnisah, Saputra, \& Azra'ie, 2016). Dalam membuat suatu keputusan pembelian, konsumen tidak terelepas dari berbagai faktorfaktor yang mempengaruhi konsumen untuk melakukan pembelian (Irawan, Marnisah, \& Azrai'e, 2018; Batu, Suryani, Septia, \& Sekaryahya, 2020). Dari faktor-faktor tersebut, maka konsumen akan melakukan penlaian terhadap berbagai alternatif pilihan, dan memilih salah satu atau lebih alternatif yang diperlukan berdasarkan pertimbangan-pertimbangan tertentu (Arifai \& Trihandayani, 2018).

Assauri (2012) mendefinisikan Keputusan Pembelian adalah suatu proses pengambilan keputusan akan pengembalian yang mencakup penentuan apa yang akan dibeli atau tidak melakukan pembelian dan keputusan itu diperoleh dari kegiatan-kegiatan sebelumnya. Swastha dan Handoko (2012) mengartikan Keputusan Pembelian adalah suatu pendekatan penyelesaian 
masalah pada kegiatan manusia untuk membeli suatu barang atau jasa dalam memenuhi keinginan, pencarian informasi, evaluasi terhadap alternatif pembelian, keputusan pembelian, dan tingkah laku setelah pembelian.

\subsection{Indikator Keputusan Pembelian}

Kotler dan Armstrong (2001) menyebutkan beberapa indikator dari keputusan pembelian, yaitu:

1. Pengenalan Masalah

Penganalisaan keinginan dan kebutuhan ini ditujukan terutama untuk mengetahui adanya keinginan dan kebutuhan yang belum terpenuhi dan belum terpuaskan. Jika kebutuhan tersebut diketahui, maka konsumen akan segera memahami adanya kebutuhan yang belum segera terpenuhi atau masih bisa ditunda pemenuhannya, serta kebutuhan yang sama harus dipenuhi. Jadi dari tahap ini proses pembelian itu mulai dilakukan, kemudian pemasar dapat mengembangkan strategi pemasaran yang memicu minat konsumen.

2. Pencarian Informasi

Konsumen yang tergugah kebutuhannya akan terdorong untuk mencari informasi yang lebih banyak mengenai produk atau jasa yang ia butuhkan. Pencarian informasi dapat bersifat aktif maupun pasif. Informasi yang bersifat aktif dapat berupa kunjungan terhadap beberapa toko untuk membuat perbandingan harga dan kualitas produk, sedangkan pencarian informasi pasif, dengan membaca suatu pengiklanan di majalah atau surat kabar tanpa mempunyai tujuan khusus dalam perkiraanya tentang gambaran produk yang diinginkan.

3. Evaluasi Alternatif

Tahap ini meliputi dua tahap, yaitu menetapkan tujuan pembelian dan menilai serta mengadakan seleksi terhadap alternatif pembelian berdasarkan tujuan pembeliannya. Tujuan pembelian bagi masing-masing konsumen tidak selalu sama, tergantung pada jenis produk dankebutuhannya. Ada konsumen yang mempunyai tujuan pembelian untuk meningkatkan prestasi, ada yang sekedar ingin memenuhi kebutuhan jangka pendeknya dan sebagainya.

4. Keputusan Pembelian

Keputusan untuk membeli disini merupakan proses pembelian yang nyata. Jadi, setelah tahap-tahap dimuka dilakukan maka konsumen harus mengambil keputusan apakah membeli atau tidak. Bila konsumen memutuskan untuk membeli, konsumen akan menjumpai serangkaian keputusan yang harus diambil menyangkut jenis produk, merek, penjual, kuantitas, waktu pembelian dan cara pembayarannya. Perusahaan perlu mengetahui beberapa jawaban atas pertanyaan-pertanyaan yang berkaitan dengan perilaku konsumen dalam keputuan pembeliannya.

5. Perilaku Pasca pembelian

Setelah membeli produk, konsumen akan mengalami suatu tingkatan kepuasan atau ketidakpuasan. Tugas pemasar tidak berakhir saat produk dibeli, melainkan berlanjut hingga periode pasca pembelian. Pemasar harus memantau kepuasan pasca pembelian, tindakan pasca pembelian, dan pemakaian produk pasca pembelian. 


\subsection{Hubungan Perilaku Konsumen Terhadap Keputusan Pembelian}

Faktor-faktor lingkungan yang mempengaruhi perilaku konsumen terdiri dari: Pertama, faktor psikologis yang mencakup: persepsi, motivasi, pembelajaran, sikap, kepercayaan dan kepribadian. Sikap dan kepercayaan merupakan faktor psikologis yang mempengaruhi keputusan pembelian konsumen. Sementara, kepribadian dalam faktor psikologis mempengaruhi perilaku konsumen, merupakan pola individu untuk merespon stimulus yang muncul dari lingkungannya. Termasuk ke dalam kepribadian adalah opini, minat dan prakarsa. Kedua, faktor situasional, merupakan faktor yang membuat pribadi seseorang untuk bersedia untu berbelanja karena didukung prasarana tempat belanja, waktu belanja, penggunaan produk, kondisi saat pembelian, dan termasuk juga dalam waktu pembelian/belanja. Ketiga, faktor sosial ini mencakup: Undang-undang/peraturan, artinya sebelum memutuskan untuk membeli suatu produk, maka konsumen harus mempertimbangkan apakah pembelian produk tersebut diperbolehkan atau tidak oleh undang-undang yang berlaku; Keluarga, artinya Pertimbangan faktor keluarga yang mencoba memberikan pemahaman bagaimana melakukan pembelian produk; Kelompok referensi; Kelas sosial; dan Budaya (seperti suku dan ras), yang dimana semua faktor tersebut terbentuk bagaimana perilaku konsumen dalam membeli/memilih dan mengkonsumsi barang dan jasa.

Dari rumusan diatas, memberikan gambaran yang jelas mengenai pentingnya memahami faktor-faktor yang mempengaruhi perilaku konsumen dalam menetapkan keputusan pembelian bagi suatu produk. Pada dasarnya, setiap konsumen memiliki pertimbangan di dalam melakukan keputusan pembelian.

\subsection{Kerangka Pemikiran Teoritis}

Kerangka pemikiran teoritis dalam penelitian ini bertujuan untuk mengetahui pengaruh perilaku konsumen terhadap keputusan penggunaan KWh meter Listrik Pascabayar dan Prabayar pada PT PLN (Persero) Ranting Pancur Batu, Kota Medan. Kerangka pemikiran pada penelitian ini terpola pada suatu alur pemikiran yang terkonsep. Secara sistematik, kerangka pemikiran teoritis dalam penelitian ini dapat digambarkan sebagai berikut:

Gambar 1. Kerangkan Pemikiran Teoritis

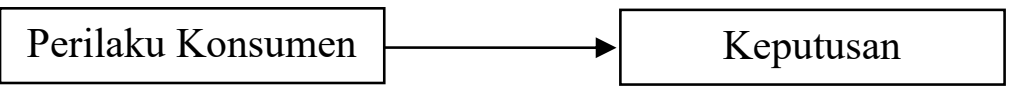

\subsection{Hipotesis}

Dari rumusan masalah dan kerangka pemikiran teoritis, maka dapat dibuat hipotesis sebagai berikut:

1. Ha: Terdapat pengaruh perilaku konsumen terhadap keputusan memilih penggunaan KWh meter Listrik Pascabayar dan Prabayar pada PT PLN (Persero) Ranting Pancur Batu, Kota Medan.

2. H0 : Tidak terdapat pengaruh perilaku konsumen terhadap keputusan memilih penggunaan KWh meter Listrik Pascabayar dan Prabayar pada PT PLN (Persero) Ranting Pancur Batu, Kota Medan. 


\section{Metode Penelitian}

\subsection{Jenis Penelitian}

Jenis penelitian ini adalah penelitian kuantitatif. Menurut Sugiyono (2010), metode penelitian kuantitatif adalah metode penelitian yang berlandaskan pada filsafat positivism yang digunakan pada populasi atau sampel tertentu, pengumpulan data menggunakan instrumenpenelitian, analisis data bersifat kuantitatif atau statistik dengan tujuan untuk menguji hipotesis yang telah ditetapkan.

\subsection{Populasi dan Sampel}

Menurut Sugiyono (2010), populasi adalah wilayah generalisasi yang terdiri dari subyek/obyek yang mempunyai kualitas dan karakteristik tertentu yang ditetapkan oleh peneliti untuk dipelajari dan kemudian di tarik kesimpulannya atau dengan kata lain apabila seseorang yang hendak meneliti semua karakteristik dan elemen dalam suatu wilayah penelitian, tentu saja penelitian tersebut temasuk dalam penelitian populasi. Populasi dalam penelitian ini adalah seluruh pelanggan penggunaan listrik pascabayar dan prabayar di Kelurahan Mangga, Kecamatan Medan Tuntungan, Kota Medan, Provinsi Sumatera Utara yang berjumlah 1.595 orang pelanggan.

Menurut Sugiyono (2010), sampel adalah bagian dari jumlah dan karakteristik atau populasi yang dimiliki. Sampel dilakukan jika populasi besar dan peneliti tidak mungkin mempelajari semua yang ada pada populasi. Dalam penelitian ini peneliti mempersempit populasi yang jumlah seluruh pelanggan sebanyak 1.595 pelanggan dengan menghitung ukuran sampel yang dilakukan dengan menggunakan rumus Slovin, karena dalam penarikan sampel, jumlahnya harus representative agar hasil penelitian dapat digenerelasasikan dan perhitungannya tidak menggunakan tabel jumlah sampel tetapi dilakukan dengan rumus dan perhitungan yang sederhana.

Rumus Slovin untuk menentukan sampel adalah sebagai berikut:

$$
n=\frac{N}{1+N(e)^{2}}
$$

Keterangan:

$\mathrm{n}=$ Ukuran sampel/jumlah responden

$\mathrm{N}=$ Ukuran populasi

$\mathrm{E}=$ Persentase kelonggaran ketelitian kesalahan pengambilan sampel yang masih bisa ditelorir $\mathrm{e}=0.1$

Dalam rumus Slovin ada ketentuan sebagai berikut: Nilai e= $0.1(10 \%)$ untuk populasi yang jumlah besar. Nilai $\mathrm{e}=0.2(20 \%)$ untuk populasi yang jumlah kecil.

Rentang sampel yang dapat diambil dari teknik Slovin adalah antara 10-20\% dari populasi penelitian. Jumlah populasi dalam penelitian ini adalah sebanyak 1.595 pelanggan, sehingga persentase kelonggaran adalah $10 \%$ dan hasil perhitungan dapat dibulatkan untuk mencapai kesesuaian maka untuk mengetahui sampel penelitian, dengan perhitungan sebagai berikut:

$$
n=\frac{N}{1+N(e)^{2}}
$$




$$
\begin{gathered}
n=\frac{1.595}{1+1.595(0.1)^{2}} \\
n=\frac{1.595}{1+1.595(0.01)} \\
n=\frac{1.595}{1+15.95} \\
n=\frac{1.595}{16.95} \\
n=94.100 \\
n=94
\end{gathered}
$$

Maka dari hasil perhitungan menggunakan rumus ini diperoleh sampel untuk penelitian ini adalah sebanyak 94 pelanggan.

\subsection{Sumber Data}

Sumber data yang digunakan dalam penelitian ini adalah:

1. Data Primer, yaitu data yang diperoleh langsung dari tempat penelitian dengan melihat kejadian atau kegiatan dan hasil dari penelitian peneliti tersebut atau data yang diperoleh tidak melalui media perantara. Data primer dapat berupa opini subjek secara individual atau kelompok, kejadian atau kegiatan, serta hasil pengujian.

2. Data Sekunder merupakan sumber data informasi yang dikumpulkan untuk menjadi dasar kesimpulan bagi suatu penelitian. Data yang dihasilkan diperoleh dari buku-buku, dokumen, peraturan, serta bacaan lain yang di jadikan teori dalam menganalisis data yang ditentukan. Data sekunder yang diperoleh dari penelitian ini adalah catatan dan dokumen yang berkaitan langsung dengan penggunaan KWh meter Listrik Pascabayar dan Prabayar pada PT PLN (Persero) Ranting Pancur Batu, Kota Medan.

\subsection{Metode Pengumpulan Data}

Menurut Sugiyono (2010) "Metode pengumpulan data adalah ketepatan cara-cara yang digunakan untuk mengumpulkan data yang dapat dilakukan dalam berbagai setting, berbagai sumber, dan berbagai cara. Pengumpulan data yang sangat penting karena menentukan baik buruknya suatu penelitian. Pengumpulan data merupakan usaha untuk memperoleh bahanbahan keterangan serta kenyataan yang benar-benar nyata dan dapat dipertanggung-jawabkan. Adapun metode yang digunakan dalam penelitian ini adalah:

1. Metode observasi, merupakan kegiatan untuk melakukan pengamatan langsung pada objek yang diteliti, sebagai proses pencatatan pola perilaku subjek (orang), objek (benda) atau kejadian-kejadian yang sistematis tanpa disertai pertanyaan dan komunikasi dengan konsumen yang diteliti. Peneliti terjun langsung ke lokasi untuk mengamati keadaan pada subyek/obyek yang diteliti.

2. Metode Wawancara atau interview, merupakan proses pengumpulan data dimana informan menjawab pertanyaan yang diajukan pewawancara secara ekslusif untuk kepentingan penelitian. Peneliti langsung melakukan wawancara tanya-jawab dengan pihak manajemen perusahaan dan beberapa karyawan yang menjadi responden penelitian yaitu tentang perilaku konsumen dan keputusan pemilihan. 
3. Daftar Pertanyaan (Kuesioner), merupakan metode pengumpulan data yang dilakukan dengan cara memberi seperangkat pertanyaan atau pernyataan tertulis kepada responden untuk dijawab. Kuesioner merupakan metode pengumpulan data yang lebih efisien jika peneliti telah mengetahui dengan pasti variabel yang akan diukur dan mengetahui yang diharapkan dari responden. Selain itu kuesioner juga cocok digunakan jika jumlah responden cukup besar dan tersebar di wilayah yang luas.Kemudian dari jawaban itu diberikan skornya dengan skala likert. Metode ini langsung dilakukan peneliti dengan membagikan kuesioner kepada konsumen yang telah ditetapkan untuk mendapatkan data yang tepat.

4. Studi Dokumentasi, merupakan kegiatan untuk melakukan pengumpulan data dengan cara membaca dan mempelajari dokumen, buku-buku, literature yang berhubungan dengan masalah yang diteliti.

\subsection{Uji Validitas dan Reliabilitas}

Data untuk keperluan analisis dan pengujian hipotesis diolah secara sistematik dengan menggunakan alat bantu program SPSS statistics versi 22. SPSS (Statistical Package for the Social Sciences) adalah aplikasi yang digunakan untuk melakukan analisis statistic data. Data yang telah diperoleh kemudian diuji dengan:

\subsubsection{Uji Validitas}

Uji Validitas digunakan untuk mengukur apakah data yang didapat setelah penelitian merupakan data yang validdengan alat ukur yang digunakan (kuesioner). Dalam penelitian ini sampel uji validitas diambil sebanyak 94 orang, dan diukur dengan menggunakan program SPSS statistics 22. Peneliti melakukan Uji Validitas ini dengan menggunakan SPSS dengan kriteria (Sugiyono, 2010) sebagai berikut:

1. Jika $\mathbf{r}_{\text {hitung }}>\mathrm{r}_{\text {tabel, }}$ maka pernyataan tersebut dikatakan valid.

2. Jika $r_{\text {hitung }}<\mathbf{r}_{\text {tabel, }}$ maka pernyataan tersebut dikatakan tidak valid.

\subsubsection{Uji Reliabilitas}

Uji Reliabilitas merupakan tingkat kendala suatu instrumen penelitian. Instrumen yang reliable adalah instrumen yang apabila berulang kali diukur menggunakanobjek yang sama akan menghasilkan data yang sama. Reliable artinya data yang diperoleh melalui kuesioner hasilnya konsisten bila digunakan untuk penelitian ini. Uji Reliabilitas dapat menunjukkan konsistensi dari jawaban-jawaban yang terdapat pada kuesioner. Uji ini dilakukan setelah uji validitas dan diuji merupakan data yang sudah valid. Valid artinya data yang diperoleh melalui kuesioner yang dapat menjawab tujuan penelitian.

Peneliti melakukan penelitian ini dengan uji reliabilitas dengan menggunakan bantuan program SPSS. Butiran pernyataan yang sudah valid dalam uji validitas akan ditentukan reliablitasnya dengan kriteria (Sugiyono, 2010) sebagai berikut:

1. Jika $\mathrm{r}_{\text {alpha }}$ positif atau $>\mathrm{r}_{\text {tabel, }}$ maka pernyataan reliable.

2. Jika $\mathrm{r}_{\text {alpha }}$ negatif atau $<\mathrm{r}_{\text {tabel }}$ maka pernyataan tidak reliable. 


\subsection{Definisi Operasional dan Pengukuran Variabel}

\subsubsection{Definisi Operasional}

Menurut Sugiyono (2010), definisi operasional adalah penentuan konstrak atau sifat yang akan dipelajari sehingga menjadi variabel yang dapat diukur. Definisi operasional menjelaskan cara tertentu yang digunakan untuk meneliti dan mengoperasikan konstrak, sehingga memungkinkan bagi peneliti lain untuk melakukan replikasi pengukuran dengan cara yang sama atau mengembangkan cara pengukuran konstrak yang baik. Sesuai dengan perumusan masalah yang ada maka dalam penelitian ini menggunakan dua variabel yaitu variabel bebas (X) yaitu Perilaku Konsumen, dan variabel terikat (Y), yaitu Keputusan Pembelian. Berikut ini disajikan tabel untuk definisi operasional.

Tabel 2. Definisi Operasional

\begin{tabular}{|c|c|c|c|c|}
\hline No & Variabel & Definisi & Indikator & Skala \\
\hline 1 & $\begin{array}{l}\text { Perilaku } \\
\text { Konsumen } \\
\text { (X) }\end{array}$ & $\begin{array}{l}\text { Perilaku konsumen adalah studi } \\
\text { bagaimana individu, kelompok dan } \\
\text { organisasi memilih, membeli, } \\
\text { menggunakan dan menempatkan } \\
\text { barang, jasa, ide atau pengalaman } \\
\text { untuk memuaskan keinginan dan } \\
\text { kebutuhan mereka. } \\
\text { (Kotler dan Keller, 2008) }\end{array}$ & $\begin{array}{l}\text { 1. Faktor Psikologis. } \\
\text { 2. Faktor Situasinal. } \\
\text { 3. Faktor Sosial } \\
\text { (Kotler dan Keller, } \\
\text { 2008) }\end{array}$ & Likert \\
\hline 2 & $\begin{array}{l}\text { Keputusan } \\
\text { Pembelian } \\
\text { (Y) }\end{array}$ & $\begin{array}{l}\text { Keputusan pembelian adalah } \\
\text { sebuah pendekatan penyelesaian } \\
\text { masalah pada kegiatan manusia } \\
\text { untuk membeli suatu barang atau } \\
\text { jasa dalam memenuhi keinginan, } \\
\text { pencarian informasi, evaluasi } \\
\text { terhadap alternatif pembelian, } \\
\text { keputusan pembelian, dan tingkah } \\
\text { laku setelah pembelian. } \\
\text { (Swastha dan Handoko, 2012) }\end{array}$ & $\begin{array}{l}\text { 1. Pengenalan masalah. } \\
\text { 2. Pencarian informasi. } \\
\text { 3. Evaluasi alternatif. } \\
\text { 4. Keputusan Pembelian. } \\
\text { 5. Perilaku Pasca } \\
\text { pembelian. } \\
\text { (Kotler dan Armstrong, } \\
\text { 2001) }\end{array}$ & Likert \\
\hline
\end{tabular}

\subsubsection{Pengukuran Variabel}

Penyusunan daftar pertanyaan kuesioner, variabel dan indikator yang akan diukur harus ditetapkan terlebih dahulu. Skala pengukuran yang digunakan untuk mengukur baik variabel bebas maupun terikat dalam penelitian ini adalah data ordinal. Skala ini memungkinkan peneliti untuk memasukkan responden ke dalam ukuran ranking atas dasar sikapnya, namun tidak memberikan nilai absolut atas suatu objek. Skala pengukuran yang akan diteliti beserta indikatornya disajikan dengan skala Likert dalam tabel berikut: 


\begin{tabular}{|l|l|l|}
\hline No. & Pernyataan & Bobot nilai \\
\hline 1 & Sangat Setuju (ST) & 5 \\
\hline 2 & Setuju (S) & 4 \\
\hline 3 & Ragu-Ragu (R) & 3 \\
\hline 4 & Tidak Setuju (TS) & 2 \\
\hline 5 & Sangat Tidak Setuju (STS) & 1 \\
\hline
\end{tabular}

\subsection{Uji Hipotesis}

Uji hipotesis merupakan metode pembuktian empiris untuk mengkonfirmasi atau menolak sebuah opini atau asumsi dengan menggunakan data sampel. Hasil penelitian hipotesis tersebut dapat dilakukan dengan menggunakan uji statistik sebagai berikut:

\subsubsection{Uji Parsial (Uji-t)}

Menurut Sugiyono (2010) Uji t yaitu uji sescara parsial untukmembuktikan hipotesis awal tentang pengaruh perilaku konsumen $(\mathrm{X})$ sebagai variable bebas terhadap keputusan pemilihan (Y) sebagai variable terikat.

Kriteria pengambilan keputusan:

Ho diterima jika $t_{\text {hitung }}<t_{\text {tabel }}$ pada $\alpha=5 \%$.

Ha diterima jika $t_{\text {hitung }}<t_{\text {tabel }}$ pada $\alpha=5 \%$.

\subsubsection{Koefisien Determinasi}

Koefisien Determinasi pada regresi linear sering diartikan sebagai seberapa besar kemampuan semua variabel bebas dalam menjelaskan varians dari variabel terikat. Menurut Sugiyono (2010), Uji Koefisien determinan digunakan untuk melihat seberapa besar kontribusi variabel bebas terhadap variabel terikat. Semakin besar nilai koefisien determinan maka semakin baik kemampuan variabel $(\mathrm{X})$ menerangkan variabel $(\mathrm{Y})$.

$\mathrm{D}=\mathrm{R}^{2} \times 100 \%$

\section{Keterangan}

$$
\begin{aligned}
& \mathrm{D}=\text { Koefisien Determinan } \\
& \mathrm{R}^{2}=\text { Koefisien Korelasi yang dikuadratkan }
\end{aligned}
$$

\section{Pembahasan}




\subsection{Uji Validitas dan Reliabilitas}

4.1.1 Uji Validitas Variabel Perilaku Konsumen (X)

Tabel 4. Perilaku Konsumen (X)

\begin{tabular}{|c|c|c|c|c|c|}
\hline & $\begin{array}{l}\text { Scale Mean if Item } \\
\text { Deleted }\end{array}$ & $\begin{array}{l}\text { Scale Variance if } \\
\text { Item Deleted }\end{array}$ & \multicolumn{2}{|c|}{$\begin{array}{l}\text { Corrected Item- } \\
\text { Total Correlation }\end{array}$} & $\begin{array}{l}\text { Cronbach's Alpha if } \\
\text { Item Deleted }\end{array}$ \\
\hline P1 & 32,8298 & 20,465 & \multicolumn{2}{|l|}{, 695} & ,909 \\
\hline $\mathrm{P} 2$ & 32,8298 & 20,809 & \multicolumn{2}{|l|}{, 614} & ,914 \\
\hline P3 & 32,8298 & 19,949 & \multicolumn{2}{|l|}{, 676} & ,910 \\
\hline P4 & 32,9362 & 19,673 & \multicolumn{2}{|l|}{, 770} & ,904 \\
\hline P5 & 32,9787 & 18,903 & \multicolumn{2}{|l|}{, 744} & ,906 \\
\hline P6 & 32,9787 & 19,914 & \multicolumn{2}{|l|}{, 742} & ,906 \\
\hline P7 & 32,9574 & 19,912 & \multicolumn{2}{|l|}{, 744} & ,905 \\
\hline P8 & 33,0106 & 20,118 & \multicolumn{2}{|l|}{, 713} & ,907 \\
\hline P9 & 32,8191 & 20,257 & \multicolumn{2}{|l|}{,687 } & ,909 \\
\hline \multicolumn{2}{|l|}{$\mathrm{r}$ hitung } & \multicolumn{2}{|l|}{$\mathrm{r}$ table } & \multicolumn{2}{|c|}{ Keterangan } \\
\hline \multicolumn{2}{|c|}{695} & \multicolumn{2}{|l|}{0,2028} & \multicolumn{2}{|l|}{ Valid } \\
\hline \multicolumn{2}{|c|}{,614 } & \multicolumn{2}{|l|}{0,2028} & \multicolumn{2}{|l|}{ Valid } \\
\hline \multicolumn{2}{|c|}{676} & \multicolumn{2}{|l|}{0,2028} & \multicolumn{2}{|l|}{ Valid } \\
\hline \multicolumn{2}{|c|}{, 770} & \multicolumn{2}{|l|}{0,2028} & \multicolumn{2}{|l|}{ Valid } \\
\hline \multicolumn{2}{|c|}{, 744} & \multicolumn{2}{|l|}{0,2028} & \multicolumn{2}{|l|}{ Valid } \\
\hline \multicolumn{2}{|c|}{,742 } & \multicolumn{2}{|l|}{0,2028} & \multicolumn{2}{|l|}{ Valid } \\
\hline \multicolumn{2}{|c|}{,744 } & \multicolumn{2}{|l|}{0,2028} & \multicolumn{2}{|l|}{ Valid } \\
\hline \multicolumn{2}{|c|}{, 713} & \multicolumn{2}{|l|}{0,2028} & Valid & \\
\hline 687 & & 0,2028 & & Valid & \\
\hline
\end{tabular}

Dari Tabel 4 di atas diketahui nilai validitas pernyataan untuk perilaku konsumen seluruhnya sudah valid karena nilai validitas seluruhnya lebih besar dari $r$ tabel $(n-2=94-2=92=0,2028)$ sehingga diperoleh bahwa pengujian dari variabel perilaku konsumen nilai Corrected Item 
Total Correlation ( $\mathrm{r}_{\text {hitung }}$ ) tertinggi pada item 4 sebesar 0,770 dengan hasil analisis $\mathrm{r}_{\text {hitung }} 0,770>$ 0,2028 dan nilai terendah pada item 2 sebesar 0,614, dan akan diperoleh hasil $\mathrm{r}_{\text {hitung }}$ $0,614>0,2028$ dan pengujian seluruh item pernyataan dari perilaku konsumen memiliki nilai yang lebih besar dari 0,2028. Dengan demikian dapat disimpulkan bahwa seluruh item pernyataan dari perilaku konsumen dinyatakan valid dan dapat digunakan dalam penelitian selanjutnya.

\subsubsection{Uji Validitas Variabel Keputusan Pembelian (Y)}

Tabel 5. Keputusan Pemilihan

\begin{tabular}{|c|c|c|c|c|c|}
\hline & $\begin{array}{l}\text { Scale Mean if Item } \\
\text { Deleted }\end{array}$ & $\begin{array}{l}\text { Scale Variance if } \\
\text { Item Deleted }\end{array}$ & \multicolumn{2}{|c|}{$\begin{array}{l}\text { Corrected Item- } \\
\text { Total Correlation }\end{array}$} & $\begin{array}{l}\text { Cronbach's Alpha } \\
\text { if Item Deleted }\end{array}$ \\
\hline $\mathrm{P} 1$ & 39.0106 & 19.150 & \multicolumn{2}{|l|}{.721} & .891 \\
\hline P2 & 39.1596 & 19.964 & \multicolumn{2}{|l|}{.584} & .899 \\
\hline P3 & 38.9894 & 17.882 & \multicolumn{2}{|l|}{.790} & .886 \\
\hline P4 & 39.1064 & 19.730 & \multicolumn{2}{|l|}{.489} & .907 \\
\hline P5 & 39.0106 & 19.150 & \multicolumn{2}{|l|}{.721} & .891 \\
\hline P6 & 39.1596 & 19.964 & \multicolumn{2}{|l|}{.584} & .899 \\
\hline P7 & 39.0106 & 19.150 & \multicolumn{2}{|l|}{.721} & .891 \\
\hline P8 & 39.1596 & 19.964 & \multicolumn{2}{|l|}{.584} & .899 \\
\hline P9 & 38.9894 & 17.882 & \multicolumn{2}{|l|}{.790} & .886 \\
\hline P10 & 39.2340 & 18.611 & \multicolumn{2}{|l|}{.649} & .896 \\
\hline \multicolumn{2}{|c|}{$r$ hitung } & \multicolumn{2}{|l|}{ r table } & \multicolumn{2}{|c|}{ Keterangan } \\
\hline \multicolumn{2}{|c|}{.721} & \multicolumn{2}{|l|}{0,2028} & \multicolumn{2}{|l|}{ Valid } \\
\hline \multicolumn{2}{|c|}{.584} & \multicolumn{2}{|l|}{0,2028} & \multicolumn{2}{|l|}{ Valid } \\
\hline \multicolumn{2}{|c|}{.790} & \multicolumn{2}{|l|}{0,2028} & \multicolumn{2}{|l|}{ Valid } \\
\hline \multicolumn{2}{|c|}{.489} & \multicolumn{2}{|l|}{0,2028} & \multicolumn{2}{|l|}{ Valid } \\
\hline \multicolumn{2}{|c|}{.721} & \multicolumn{2}{|l|}{0,2028} & \multicolumn{2}{|l|}{ Valid } \\
\hline \multicolumn{2}{|c|}{.584} & \multicolumn{2}{|l|}{0,2028} & \multicolumn{2}{|l|}{ Valid } \\
\hline \multicolumn{2}{|c|}{.721} & \multicolumn{2}{|l|}{0,2028} & \multicolumn{2}{|l|}{ Valid } \\
\hline
\end{tabular}




\begin{tabular}{|l|l|l|}
\hline .584 & 0,2028 & Valid \\
\hline .790 & 0,2028 & Valid \\
\hline .649 & 0,2028 & Valid \\
\hline
\end{tabular}

Dari Tabel 5 di atas diketahui nilai validitas pernyataan untuk keputusan pemilihan seluruhnya sudah valid karena nilai validitas seluruhnya lebih besar dari $r$ tabel $(n-2=94-2=92=0,2028)$ sehingga diperoleh bahwa pengujian dari variabel keputusan pemilihan nilai Corrected Item Total Correlation ( $\mathrm{r}_{\text {hitung }}$ ) tertinggi pada item 1,5 dan 7 sebesar 0,757 , dimana hasil analisis $\mathrm{r}_{\text {hitung }}$ $0,757>0,2028$ dan nilai terendah pada item 4 sebesar 0,498 sehingga akan diperoleh hasil $r_{\text {hitung }}$ $0,498>0,2028$ yaitu pengujian seluruh item pernyataan dari keputusan pemilihan memiliki nilai yang lebih besar dari 0,2028. Dengan demikian dapat disimpulkan bahwa seluruh item pernyataan dari keputusan pemilihan dinyatakan valid dan dapat digunakan dalam penelitian selanjutnya.

\subsection{Uji Reliabilitas}

Tabel 6. Hasil Uji Reliabilitas Instrumen

\begin{tabular}{|l|l|l|l|}
\hline Variabel & Cronbach Alpha & Taraf Alpha & Keterangan \\
\hline Perilaku Konsumen (X) & 0,917 & 0.6 & Reliabel \\
\hline Keputusan Pemilihan (Y) & 0,904 & 0.6 & Reliabel \\
\hline
\end{tabular}

Berdasarkan tabel 6 di atas diketahui nilai Cronbach Alpha untuk seluruh variabel perilaku konsumen sebesar 0,917>0,6 sehingga variabel dikatakan sudah handal sedangkan variabel keputusan pemilihan sebesar 0,896>0,6. Berdasarkan nilai Cronbach Alpha untuk variabel perilaku konsumen dan keputusan pemilihan lebih besar dari taraf alpha penolakan sehingga dapat dinyatakan bahwa kedua variabel yaitu perilaku konsumen dan keputusan pemilihan sudah handal.

\subsection{Hasil Uji Statistik}

\subsubsection{Analisis Regresi Linier Sederhana}

Untuk mempermudah pembacaan hasil dan interpretasi analisis regresi maka digunakan persamaan. Persamaan atau model tersebut berisi konstanta dan koefisien-koefisien regresi yang didapat dari hasil pengolahan data yang telah dilakukan sebelumnya. Persamaan regresi yang telah dirumuskan kemudian dengan bantuan program SPSS dilakukan pengolahan data sehingga didapat persamaan akhir sebagai berikut:

Tabel 7. Hasil Analisis Regresi Sederhana

\begin{tabular}{|c|c|c|c|c|c|c|c|}
\hline \multirow[b]{2}{*}{ Model } & \multicolumn{2}{|c|}{$\begin{array}{l}\text { Unstandardized } \\
\text { Coefficients }\end{array}$} & \multirow{2}{*}{$\begin{array}{l}\text { Standardized } \\
\text { Coefficients }\end{array}$} & \multirow[b]{2}{*}{$\mathrm{t}$} & \multirow[b]{2}{*}{ Sig. } & \multicolumn{2}{|c|}{$\begin{array}{l}\text { Collinearity } \\
\text { Statistics }\end{array}$} \\
\hline & B & Error & & & & Tolerance & VIF \\
\hline
\end{tabular}




\begin{tabular}{|l|l|l|l|l|l|l|l|l|}
\hline 1 & (Constant) & 18.684 & 2.717 & & 6.876 & .000 & & \\
\cline { 2 - 9 } & $\mathrm{X}$ & .668 & .073 & .692 & 9.187 & .000 & 1.000 & 1.000 \\
\hline
\end{tabular}

a. Dependent Variable: Y

Berdasarkan Tabel 7 di atas, maka persamaan regresi linier sederhana dalam penelitian ini adalah:

$$
\mathrm{Y}=18,684+(\mathrm{X}) 0,668+\mathrm{e}
$$

1. Pada model regresi ini, nilai konstanta yang tercantum sebesar 18,684 dapat diartikan jika variabel bebas dalam model diasumsikan sama dengan nol maka secara rata-rata variabel diluar model tetap akan meningkatkan keputusan pemilihan tetap sebesar 18,684 satusatuan atau dengan kata lain jika variabel perilaku konsumen tidak ditingkatkan, maka keputusan pemilihan masih sebesar 18,684 satuan.

2. Nilai besaran koefisien regresi $\beta$ sebesar 0,668 pada penelitian ini dapat diartikan bahwa variabel perilaku konsumen berpengaruh positif terhadapkeputusan pemilihan pada PT PLN (Persero) Ranting Pancur Batu, Kota Medan. Hal ini menunjukkan bahwa ketika perilaku konsumen mengalami peningkatan sebesar satu satuan, maka keputusan pemilihan penggunaan KWh meter Pascabayar dan Prabayar pada PT PLN (Persero) Ranting Pancur Batu, Kota Medan juga akan mengalami peningkatan sebesar 0,668 satuan.

\subsubsection{Uji Parsial (Uji t)}

Hasil pengujian hipotesis pertama secara parsial dapat dilihat pada tabel IV.5 berikut:

Tabel 8. Hasil Uji t

\begin{tabular}{|c|c|c|c|c|c|c|c|c|}
\hline \multirow{2}{*}{\multicolumn{2}{|c|}{ Model }} & \multicolumn{2}{|c|}{$\begin{array}{l}\text { Unstandardized } \\
\text { Coefficients }\end{array}$} & \multirow{2}{*}{\begin{tabular}{|l} 
Standardized \\
Coefficients \\
Beta
\end{tabular}} & \multirow[b]{2}{*}{$\mathrm{t}$} & \multirow[b]{2}{*}{ Sig. } & \multicolumn{2}{|c|}{$\begin{array}{l}\text { Collinearity } \\
\text { Statistics }\end{array}$} \\
\hline & & B & $\begin{array}{l}\text { Std. } \\
\text { Error }\end{array}$ & & & & Tolerance & VIF \\
\hline \multirow[t]{2}{*}{1} & (Constant) & 18.684 & 2.717 & & 6.876 & .000 & & \\
\hline & $X$ & .668 & .073 & .692 & 9.187 & .000 & 1.000 & 1.000 \\
\hline
\end{tabular}

a. Dependent Variable: Y

Dari Tabel 8 di atas diperoleh hasil sebagai berikut:

Nilai signifikansinya untuk variabel perilaku konsumen $(0,000)$ lebih kecil dibandingkan dari alpha $5 \%(0,05)$ atau $\mathrm{t}$ hitung $=9.187>\mathrm{t}$ table $(\mathrm{n}-\mathrm{k}=94-2=92=1,9860)$. Berdasarkan hasil yang diperoleh maka menolak $\mathrm{H}_{0}$ dan menerima $\mathrm{Ha}$ untuk variabelperilaku konsumen. Dengan demikian, secara parsial bahwa variabel perilaku konsumen berpengaruh positif dan signifikan terhadap keputusan pemilihan penggunaan KWh meter Pascabayar dan Prabayar pada PT PLN (Persero) Ranting Pancur Batu, Kota Medan. 


\subsubsection{Koefisien Determinasi $\left(\mathrm{R}^{2}\right)$}

Nilai koefisien determinasi $\left(\mathrm{R}^{2}\right)$ dipergunakan untuk mengukur besarnya hubungan variabel bebas yang terdiri dari variabel perilaku konsumen terhadap keputusan pemilihan pemilihan penggunaan KWh meter Pascabayar dan Prabayar pada PT PLN (Persero) Ranting Pancur Batu, Kota Medan. Hasil Uji determinasi dapat dilihat berikut:

Tabel 9. Hasil Uji Koefisien Determinasi

\begin{tabular}{|l|l|l|l|l|l|}
\hline Model & R & R Square & $\begin{array}{l}\text { Adjusted } \\
\text { Square }\end{array}$ & $\begin{array}{l}\text { Std. Error of the } \\
\text { Estimate }\end{array}$ & Durbin-Watson \\
\hline 1 & $.692^{\mathrm{a}}$ & .478 & .473 & 3.51133 & 1.438 \\
\hline
\end{tabular}

a. Predictors: (Constant), X

b. Dependent Variable: Y

Berdasarkan Tabel 8 diperoleh nilai regresi korelasi sebesar 0,692 artinya secara bersama-sama perilaku konsumen terhadap keputusan pemilihan penggunaan KWh meter Pascabayar dan Prabayar pada PT PLN (Persero) Ranting Pancur Batu, Kota Medan memiliki kontribusi pada taraf yang erat dan positif, kemudian Adjusted $R$ Square sebesar 0,473 (47,3\%) sehingga dapat dikatakan bahwa 47,3\% variasi variabel bebas perilaku konsumen pada model memiliki kontribusi untuk variabel keputusan pemilihan, sedangkan sisanya sebesar $(52,7 \%)$ dipengaruhi oleh variabel lain di luar model.

\section{Kesimpulan}

Dari hasil penelitian dan pembahasan pada bab sebelumnya dapat disimpulkan sebagai berikut:

1. Hasil uji validitas untuk variabel perilaku konsumen dan keputusan pemilihan semua sudah valid karena nilai total item correlation $\mathrm{r}_{\text {hitung }}>\mathrm{r}_{\text {tabel }}$ sedangkan hasil uji reliabilitas nilai cronbach alpha untuk variabel perilaku konsumen dan keputusan pemilihan>nilai reliabilitas sehingga dapat dinyatakan reliabel dan handal.

2. Hasiluji t menunjukkan bahwa secara parsial variable perilaku konsumen berpengaruh positif dan signifikan terhadap keputusan pemilihan. Hal ini dapat dilihat dari nilai signifikansi untuk variable perilaku konsumen $<$ dari nilai alpha atau dimana $t_{\text {hitung }}>t_{\text {tabel }}$.

3. Secara keseluruhan didapat pengaruh positif dan signifikan perilaku konsumen (X) terhadap keputusan pemilihan $(\mathrm{Y})$ dimana nilai $\mathrm{F}_{\text {hitung }}>\mathrm{F}_{\text {tabel. }}$.

4. Hasil determinasi diperoleh dari perilaku konsumen (X) dapat menghasilkan hubungan yang erat terhadap keputusan pemilihan (Y).

5. Berdasarkan hasil uji $\mathrm{t}$ diketahui bahwa secara parsial variabel perilaku konsumenberpengaruh positif dan signifikan terhadap keputusan pemilihan. Hal ini dapat dilihat dari hasil uji t dimana, nilai signifikansinya untuk variabel perilaku konsumen $(0,000)$ lebih kecil dibandingkan dengan dari alpha $5 \%(0,05)$ atau $\mathrm{t}$ hitung $=9,187>\mathrm{t}$ table $(\mathrm{n}-\mathrm{k}=94-2=92=1,9860)$. Berdasarkan hasil yang diperoleh maka menolak $\mathrm{H}_{0}$ dan menerima Ha untuk variabel perilaku konsumen. Dengan demikian, secara parsial bahwa variabel perilaku konumen berpengaruh positif dan signifikan terhadap keputusan pemilihan 
penggunaan KWh meter Pascabayar dan Prabayar pada PT PLN (Persero) Ranting Pancur Batu, Kota Medan.

\section{Referensi}

Arifai, A. A., \& Trihandayani, Z. (2018). HARGA, KUALITAS PRODUK DAN MEREK TERHADAP KEPUTUSAN PEMBELIAN TAS KW CARTIER DI KALANGAN MAHASISWI SEBAGAI PENUNJANG PENAMPILAN KULIAH. Jurnal Ilmiah Ekonomi Global Masa Kini, 8(3), 16-22.

Assauri, Sofjan. (2012). Manajemen Pemasaran. Jakarta, Rajawali.

Batu, R. L., Suryani, N. I., Septia, N., \& Sekaryahya, P. F. (2020). Pengaruh Harga dan Inovasi Layanan Aplikasi terhadap Keputusan Penggunaan Jasa Taksi Express: Survei pada Pengunduh Aplikasi Express Taxis. Jurnal Nasional Manajemen Pemasaran \& SDM, 1(01), 1-22. https://doi.org/10.47747/jnmpsdm.v1i01.6

Engel, James F., et al. (2006). Perilaku Konsumen (terjemahan). Jilid 1. Jakarta, Penerbit Binarupa Aksara.

Irawan, D., Marnisah, L., \& Azrai'e, K. R. (2018). ANALISIS PRODUK DAN HARGA TERHADAP KEPUTUSAN MAHASISWA UNIVERSITAS IGM MEMBELI SMARTPHONE SAMSUNG. Jurnal Ilmiah Ekonomi Global Masa Kini, 8(2), 35-41.

Kotler, Philip., dan Armstrong, Gary. (2001). Prinsip-Prinsip Pemasaran (terjemahan). Jilid 1. Jakarta, Penerbit Erlangga.

Kotler, Philip., dan Keller, Kevin Lane. (2008). Manajemen Pemasaran (terjemahan). Jakarta, Penerbit Indeks.

Marnisah, L., Saputra, D., \& Azra'ie, K. R. (2016). ANALISA EFEKTIFITAS PROMOSI TERHADAP KEPUTUSAN KONSUMEN PADA MEMBELI SEMEN BARURAJA DI KELURAHAN SEKIP JAYA KECAMATAN KEMUNING PALEMBANG. Jurnal ilmiah Ekonomi Global masa kini, 7(3), 16-20.

Pangestu, Singgih. Persepsi Masyarakat Tentang Pelayanan Listrik Prabayar dan Pascabayar oleh PT PIN (Persero). Jurnal Pemerintah Integratif, September 2017, 2, hal. 297-306.

Peter, J. Paul., dan Olson, Jerry C. (2008). Perilaku Konsumen dan Strategi Pemasaran: Rencana, Strategi, Marketing (terjemahan). Jilid 1. Jakarta, Penerbit Salemba Empat.

Sugiyono . (2010). Metode Penelitian Bisnis. Bandung, Penerbit Alfabeta.

Sugiyono. (2010). Metode Penelitian Kuantitatif, Kualitatif, dan R\&D. Bandung, Penerbit Alfabeta.

Swastha, Basu D., dan Handoko, T. Hani. (2012). Manajemen Pemasaran: Analisis Perilaku Konsumen. Yogyakarta, BPFE. 